\title{
Morphology and ontogeny of some Middle Ordovician gonambonitid brachiopods from Baltoscandia
}

\author{
Anna A. Madison \\ Acta Palaeontologica Polonica 63 (3), 2018: 585-594 doi:https://doi.org/10.4202/app.00488.2018
}

The Volkhovian-Kunda boundary deposits of the Leningrad Region contain two closely related genera, Antigonambonites and Anchigonites. The latter genus was previously known only by valve moulds; here its shell exterior and interior, and ontogeny are described in detail based on the collection of well-preserved disarticulated valves of Anchigonites conulus . Antigonambonites and Anchigonites share similar developmental and morphological features, and ecological strategies including the attachment by cementation by a "pedicle tube" and are thus possibly phylogenetically related. A new diagnosis for the genus Anchigonites and description of A. conulus are provided; other species of Anchigonites are briefly revised. The moulds of outer epithelial cells are described for the first time for the class Strophomenata.

Key words: Brachiopoda, Gonambonitidae, morphology, ontogeny, Ordovician, Russia.

Anna A. Madison [sunnyannmad@yahoo.com], Borissiak Paleontological Institute of Russian Academy of Sciences, 123, Profsoyuznaya ul., Moscow, 117997 Russia.

This is an open-access article distributed under the terms of the Creative Commons Attribution License (for details please see creativecommons.org), which permits unrestricted use, distribution, and reproduction in any medium, provided the original author and source are credited. 